\title{
A identificação do meio urbano através da imaginabilidade da cidade:o caso de Londrina
}

\section{The identification of the urban environment through the imaginability of the city: the case of Londrina}

\author{
Olívia Orquiza de Carvalho', Paulo Cesar Boni²
}

\begin{abstract}
Resumo
O presente artigo trata do modo como os habitantes de Londrina vêem a cidade, com base nos conceitos de semiótica urbana, legibilidade, imaginabilidade e iconicidade. Utilizou-se a metodologia histórica, realizada pela interpretação iconográfica, juntamente ao método dedutivo apoiado nos questionários distribuídos a uma parcela de cidadãos londrinenses. A discussão focaliza a necessidade vital que os seres possuem para estruturar e identificar o ambiente na busca do sentimento de equilíbrio e bem estar. Nesse processo de orientação, a imagem ambiental que cada um possui se apresenta como o elo estratégico entre o ser e o mundo. Os resultados permitem afirmar que Londrina esta perdendo suas qualidades imagéticas e, sua identificação por seus habitantes.
\end{abstract}

Palavras-chave: Semiótica Urbana. Legibilidade. Iconicidade. Imaginabilidade.

\begin{abstract}
The present article addresses the way the inhabitants of Londrina perceive the city, based on concepts of urban semiotics, legibility, imaginability and iconicity. Historic methodology, carried out through iconographic interpretation, was used along with the deductive method, which was, in turn, supported by questionnaires distributed to a portion of the citizens of Londrina. The discussion focuses on the strong need that the subjects have for structure and identification of the environment in their search for a sense of balance and well being. In this orientation process, the environmental image that each one possesses is presented as the strategic link between themselves and the world. The results show that Londrina is losing its image qualities and its identification by its inhabitants.
\end{abstract}

Keywords: Urban Semiotic. Legibility. Iconicity. Imageability.

\section{Introdução}

Estruturar e identificar o ambiente são capacidades vitais e necessárias para o sentimento de equilíbrio e bem-estar de todos os seres que se locomovem, e isso pode ser facilmente evidenciado pela angústia, ou o até mesmo sentimento de terror, que acompanha o contratempo da desorientação espacial. De fato, muitos são os tipos de indicadores utilizados no processo de orientação: as sensações visuais (cor, forma, movimento ou polarização da luz), o olfato, a audição, o tato, a sinestesia, o sentido de gravidade e até mesmo a sensibilidade a campos elétricos e magnéticos.

Segundo Kevin Lynch (1997), no processo de orientação, o elo estratégico é a imagem ambiental, ou seja, o quadro mental generalizado do mundo

\footnotetext{
${ }^{1}$ Aluna do Curso de Especialização em Fotografia: Práxis e discurso fotográfico do Departamento de Comunicação, da Universidade Estadual de Londrina

${ }^{2}$ Doutor em Ciências da Comunicação pela Universidade de São Paulo. Professor da Universidade Estadual de Londrina. Coordenador do Curso de Especialização em Fotografia: Práxis e Discurso Fotográfico e do Mestrado em Comunicação da Universidade Estadual de Londrina. Editor da revista Discursos Fotográficos. Pesquisador e líder do Grupo de Pesquisa Comunicação e História, cadastrado no CNPq.
} 
físico exterior de que cada indivíduo é portador. Essa imagem é produto tanto da sensação imediata, quanto da lembrança de experiências passadas que ela evoca. É sobre este prisma que o presente trabalho será focado, uma vez que tomou como objetivo a análise da percepção da cidade de Londrina por seus habitantes, com base nos conceitos de semiótica urbana, legibilidade, imaginabilidade ou iconicidade, que serão apresentados na sequência do trabalho.

A metodologia histórica utilizada foi utilizada por meio da interpretação iconográfica de registros fotográficos históricos da cidade de Londrina e entrevistas com seus antigos e atuais moradores.

Ademais, ressaltamos que os resultados apresentados são passíveis de conduzirem a diferentes conclusões, tendo em vista o reduzido número de entrevistados (quando comparado ao número total da população) e também o fato de serem resultados da interpretação iconográfica da autora, pois, em qualquer interpretação, o mundo do interpretador interfere nas suas conclusões.

\section{A Semiótica Urbana}

Segundo Lucia Santaella (2005a), fenômeno é tudo aquilo que aparece à percepção e à mente, e a fenomenologia tem por objetivo apresentar as categorias formais e universais dos modos como os fenômenos são apreendidos pela mente. Dizia Peirce:

A fenomenologia ou doutrina das categorias tem por função desenredar a emaranhada meada daquilo que, em qualquer sentido, aparece, ou seja, fazer a análise de todas as experiências é a primeira tarefa a que a filosofia tem de se submeter. Ela é a mais difícil de suas tarefas, exigindo poderes de pensamento muito peculiares, a habilidade de agarrar nuvens, vastas e intangíveis, organizá-las em disposição ordenada, recolocá-las em processo (SANTAELLA, 2005b, p. $33)$.
A partir de estudos envolvendo a fenomenologia, Charles Sanders Peirce configurou a existência de três elementos formais e universais que ocorrem gradualmente em toda e qualquer experiência apresentada à consciência: a primeiridade (consciência imediata; pura qualidade de ser e de sentir); a secundidade (evolução parcial, independente do pensamento, mas pensável, gerada por um processo de reação ao estimulo inicial que origina conexões entre este e outro campo fenomenológico); e a terceiridade (aproximação das duas primeiras categorias através da síntese intelectual).

Santaella afirma, ainda, que de todas as aparências sensíveis, o homem desvela significações e é no homem e pelo homem que se opera o processo de alteração dos sinais em signos ou linguagens, sendo a semiótica a ciência que tem por objetivo o estudo de todas as linguagens.

[...] o signo é uma coisa que representa uma outra coisa: seu objeto. Ele só pode funcionar como signo se carregar esse poder de representar, substituir uma outra coisa diferente dele. [...] o signo só pode representar seu objeto para um intérprete, e porque representa seu objeto, produz na mente desse intérprete alguma outra coisa (um signo ou quase-signo) que também está relacionada ao objeto não diretamente, mas pela mediação do signo (SANTAELLA, 2005b, p. 58).

Após essa explanação, pode-se entender a cidade como um acúmulo de signos que contextualizam o ambiente, por meio da qualificação do espaço e a conseqüente identificação física, social, cultural e econômica.

Estas características de identificação da cidade, seu uso, suas transformações e suas relações podem ser apreendidas pela Semiótica e quando mapeadas e analisadas tornam-se importante instrumento para o planejamento urbano. (SILVA, 2001).

Segundo Canevacci (1993, p. 17), os milhares de signos espalhados pela urbe são responsáveis pela polifonia da cidade (cidade polifônica), ou seja, a cidade se caracteriza pela sobreposição de 
vozes, pela multiplicidade, pela transversalidade, pelo conflito, pela sobreposição de melodias e harmonias, ruídos e sons, regras e improvisações cuja soma total, simultânea ou fragmentária, comunica o sentido da obra.

Portanto, conhecer a cidade e explorá-la em suas multiplicidades, em suas multireferencialidades implica além de assumi-la como uma arena cultural, no dizer de Richard Morse (1998), assumi-la também como signo como a caracteriza Angel Rama (TAVARES, 1985).

\section{Legibilidade, Imaginabilidade, Iconicidade e identidade}

De acordo com Kevin Lynch, as imagens ambientais são o resultado de um processo bilateral entre o observador e seu ambiente. Desse modo, a imagem de uma determinada realidade pode variar significativamente entre observadores diferentes, uma vez que cada cidadão tem vastas associações com partes de sua cidade e a imagem de cada um está impregnada de lembranças e significados.

Por outro lado, estudos indicam que parece existir um consenso substancial entre membros do mesmo grupo e essas imagens de grupo são o que interessa aos planejadores urbanos dedicados à criação de um ambiente que venha a ser utilizados por várias pessoas. Essas imagens mentais comuns a vastos contingentes de habitantes de uma cidade foram chamadas por Lynch de imagens públicas.

Dessa forma, uma cidade legível seria aquela cujos bairros, marcos ou vias são facilmente reconhecíveis e agrupados num modelo geral, mas isso só é possível quando a cidade é imaginável, ou seja, com muitos símbolos conhecidos e associados entre si por caminhos também bastantes conhecidos.
[...] imaginabilidade: a característica, num objeto físico, que lhe confere uma alta probabilidade de evocar uma imagem forte em qualquer observador dado. É aquela forma, cor ou disposição que facilita a criação de imagens mentais claramente identificadas, poderosamente estruturadas e extremamente úteis do ambiente (LYNCH, 1997, p. 11).

Para Lynch, uma cidade altamente imaginável seria bem formada, distinta, digna de nota e convidaria o olho e o ouvido a uma atenção e participação maiores. Um exemplo é a cidade de Veneza, que propicia a formação mental de sua imagem quase simultânea ao ouvir ou ler o seu nome. Decorre disso que uma imagem viável requer, primeiro, uma identidade, ou seja, individualidade ou unicidade, e isso implica sua diferenciação de outras coisas. Dessa maneira, um ambiente urbano belo e aprazível constitui uma singularidade, ou, como diriam alguns, uma impossibilidade.

A isso, Lucrécia Ferrara, no livro Os Significados Urbanos (FERRARA, 2000), deu o nome de iconicidade. Segundo a autora, para entender a produção da imagem urbana é necessário refletir a respeito da lógica da imagem.

O primeiro e mais importante traço distintivo da imagem [...] diz respeito à sua iconicidade (grifo nosso), isto é, àquele tipo de representação que exige, nos processos de emissão e recepção comunicativa, uma complexa operação associativa que labora uma comparação, não apenas entre elementos, objetos, fatos, situações concretamente comparáveis, mas como uma realidade outra, produzida pela mente que compara. Essa iconicidade não é própria ou necessariamente figurativa, mas diz respeito a um modo de produzir conhecimento. [.....(FERRARA, 2000, p. 57) 
Ferrara complementa, ainda, que a questão da imagem vai muito além da sua visibilidade: ela é polissensorial e sua visibilidade é uma forma abrangente de alcançar sua semiótica.

Assim, parece clara a necessidade do equilíbrio nesta busca pela imaginabilidade ou iconicidade das cidades, pois os prazeres sensoriais estão justamente no inesperado ocorrido durante a visão serial do transeunte, e não na monotonia de muitas imagens fortes amontoadas umas ao lado das outras.

Esta idéia pode ser bem apreendida por aquilo a que Gordon Cullen (1984) chama de arte do relacionamento. Segundo Cullen, essa arte possui o objetivo de despertar a emoção ou o interesse com a reunião dos elementos que concorrem para a criação de um ambiente, ou seja, os edifícios, os anúncios, o tráfego, as árvores, a água e toda a natureza. Cullen defende que uma cidade é, antes de tudo, uma ocorrência emocionante no meio ambiente, então, se ao cabo de todo o esforço despendido para torná-la realidade, ela se apresentar monótona, não característica, ou amorfa, ela não cumprirá a sua missão, e será um fracasso.

Tal conceito também é defendido por Lynch (1997), quando afirma existir algum valor na mistificação, no labirinto ou na surpresa provocada pelo ambiente. Entretanto, o autor conclui que este valor só existe se não houver risco de perder a forma básica ou a orientação, ou seja, a confusão deve darse em pequenas regiões dentro de um todo visível, uma vez que o caos total, sem qualquer indício de conexão, não é nunca agradável.

Pelo exposto, conclui-se que as cidades exercerão melhor o papel de propiciar mais belos, mais sensoriais e melhores espaços para a vida e relações humanas quanto maiores forem suas rotas inteligíveis que marcarem o cotidiano de seus habitantes, ou seja, quanto mais pontos de identificação e caminhos conhecidos se destacarem no todo apreendido da mesma.

\section{Olhares de Londrina - a pesquisa}

Para tentar compreender quais são os pontos referenciais da cidade de Londrina provocadores de alta imaginabilidade em seus habitantes, e, também, descobrir se realmente existem ícones que consigam representá-la, foram distribuídos, em diferentes pontos da cidade (estabelecimentos comerciais do centro, instituições de ensino superior, alguns bairros e algumas clínicas), 300 questionários do Tipo 01 e 200 questionários do Tipo 02.

O questionário do Tipo 01 era uma versão completa de investigação dos dados necessários para análise. Ele é composto por 11 perguntas que, além das informações pessoais do entrevistado (para análise de seu perfil), também apresentam uma relação mais complexa de interrogações sobre a sua percepção da cidade. Assim, era requisitado aos respondentes que eles pensassem na cidade como um todo, a princípio, e depois apenas na área central, identificando os pontos de referência que os ajudavam a se locomover com segurança.

Também foi perguntado se eles acreditavam na existência de alguma referência física em Londrina que fosse marcante o suficiente a ponto de ser possível relacionar a imagem desta referência rapidamente à cidade (como o Cristo Redentor é para o Rio de Janeiro ou a Torre Eiffel para Paris etc.).

Por fim, era solicitado que desenhassem (durante a $1^{\text {a }}$ Etapa de distribuição dos questionários), ou descrevessem (durante a $2^{\text {a }}$ Etapa), o caminho entre suas respectivas casas e seus locais de trabalho, mas sempre eram lembrados de identificar os marcos referenciais (ver detalhes no Anexo I).

O questionário do Tipo 02 foi desenvolvido para se obter maior abrangência de opiniões referentes a uma das indagações relativas à percepção da cidade de Londrina, pois se considerou essa percepção de extrema importância para análise deste trabalho. A questão foi assim formulada: Qual é o Principal Marco Referencial de Londrina? (ver pormenores, no Anexo II). 
Segue abaixo a análise dos resultados das entrevistas, ressaltando-se que para o diagnóstico do questionário Tipo 01 foram considerados 156 entrevistados e, para o questionário Tipo 02 , 130, uma vez que esse foi o número de cidadãos londrinenses que apresentaram respostas plausíveis.

\section{Olhares de Londrina - os resultados}

Com o intuito de se fazer uma análise socialmente abrangente, buscou-se uma grande variação quanto ao perfil dos entrevistados. Em suma, suas idades variaram entre 16 e 82 anos e suas profissões abrangeram praticamente todas as áreas de atuação: servidores públicos, professores $\left(1^{\circ}, 2^{\circ}\right.$

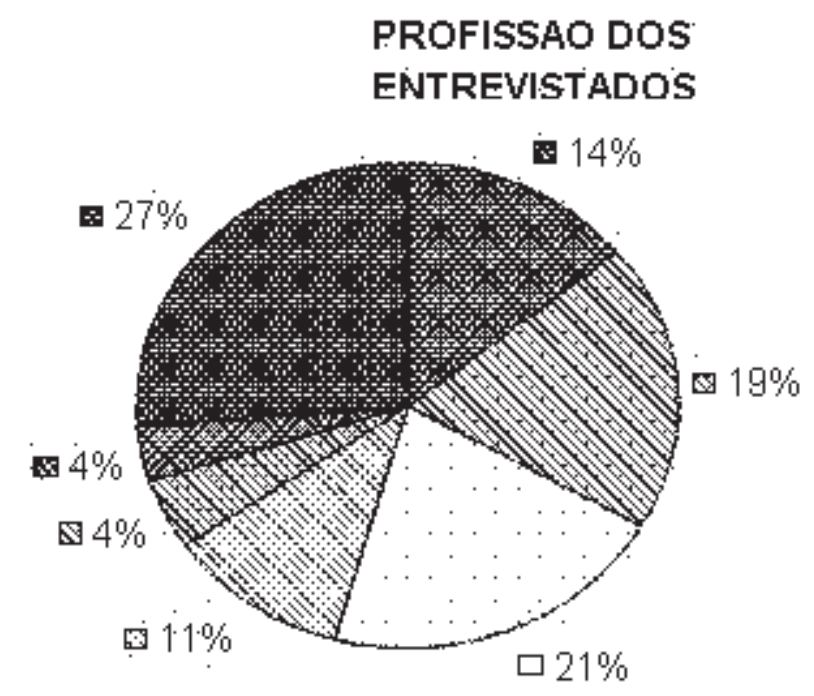

PROFISSAO DOS ENTREVISTADOS

- Funcionário Fúblico Bstudante $\square$ Comerciantes. 因 Arquiteto.e Urbanista

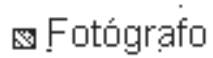

- Profisșional da Saúde

- Prófissional.Autôngmo

Gráfico 1. Profissões dos entrevistados Fonte: Elaborado pela autora

Quando questionados acerca da locomoção em Londrina, mais da metade das pessoas respondeu ter facilidade em andar pela cidade sem se perder, e $3^{\circ}$ grau), estudantes $\left(1^{\circ}, 2^{\circ}\right.$ e $3^{\circ}$ grau), Fotógrafos, Artistas Plásticos, Músicos, Bailarinos, Produtor Cultural, Arquitetos e Urbanistas, Engenheiros, Administradores, Comerciantes, Advogado, Jornalistas, Publicitários, Dentista, Fisioterapeuta, Clínico Geral, Diarista, Porteiros, Veterinário, Webdesigners, entre outros campos de atividade.

Contudo, como se pode observar no gráfico abaixo, dois ramos de atuação foram privilegiados: os fotógrafos e os arquitetos-urbanistas. Isso se deu devido ao seu maior potencial de percepção da cidade levando em conta seus estudos e a prática profissional, uma vez que estes necessariamente valorizam o exercício do olhar e buscam o entendimento da cidade. 


\section{FACHLDADE DE LOCOMOCZAO PELA CLDADE

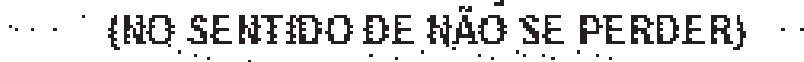

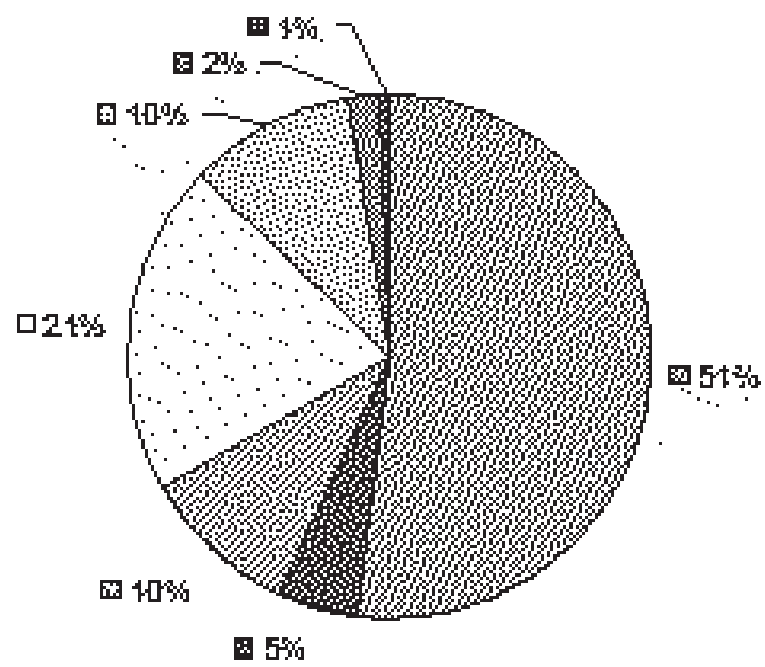

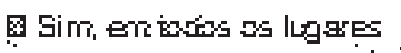

D Jï日

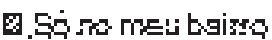

प

G For snje passo selireirgnente

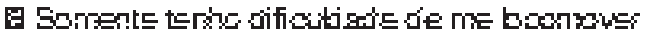
ra $Z$ 다. log lote

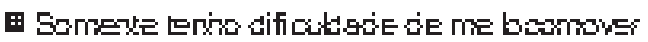
n:a Zing Sit

Gráfico 2. Facilidade de Locomoção pela cidade Fonte: Elaborado pela autora

Em contrapartida, a maior parte dos 5\% que responderam não ter facilidade de locomoção na cidade inteira, mora há mais de 20 anos nela. Isso demonstra o tanto que se demora a realmente absorver toda a imensidão de uma cidade grande como Londrina, e, consequentemente, ter a percepção da quão complexa ela é, principalmente quando ela cresce desenfreadamente e as pessoas mantêm-se presas aos caminhos rotineiro, limitando sua percepção da cidade ao percurso bairro/centro/ trabalho - trabalho/centro/bairro.

Esse fato se torna mais ao se observar o seguinte: muitas das pessoas que afirmaram locomover-se bem por toda a cidade, revelaram não ter noção do local onde se inicia e/ou termina determinado bairro, e citaram, por exemplo, o lago Igapó, a Rodoviária e/ou a Av. Madre Leônia Mílito como marcos referenciais do centro da cidade.

Com relação aos marcos referenciais da cidade de Londrina (primeiramente vista como um todo), pode-se afirmar que as grandes avenidas e os shoppings se apresentam no topo da escala dos marcos de alta identificação do transeunte com seu meio. A Avenida Higienópolis foi citada por $49 \%$ dos entrevistados como um dos pontos de referência que melhor os ajudam a locomover-se pela cidade, seguida da Avenida Juscelino Kubitschek com 47,5\% e os Shoppings Catuaí e Roya,1 com 30\%.

Na seqüência, aparecem o Lago Igapó (29\%), o Calçadão (27,5\%), a Catedral (26,5\%) e a Rodoviária, sendo esta citada por $24 \%$ das pessoas, como se observa no gráfico seguinte.

O gráfico 04 nos permite, ainda, verificar que pontos históricos importantes - como o Museu de Arte (2,5\%), o Museu Histórico (3\%), o Bosque (2,5\%), a Concha Acústica (2,5\%) e o Teatro Ouro Verde $(0 \%)$ - revelam estar praticamente extintos da mente dos londrinenses quando analisados em grande escala.

Mais impressionante é o fato de que alguns desses edifícios históricos - Museus e Teatro - aparentam estar, também, esquecidos quando analisados em escala menor, como confirma o gráfico 04 relativo aos marcos referenciais do centro da cidade que melhor ajudam o transeunte a identificar-se com o meio. 


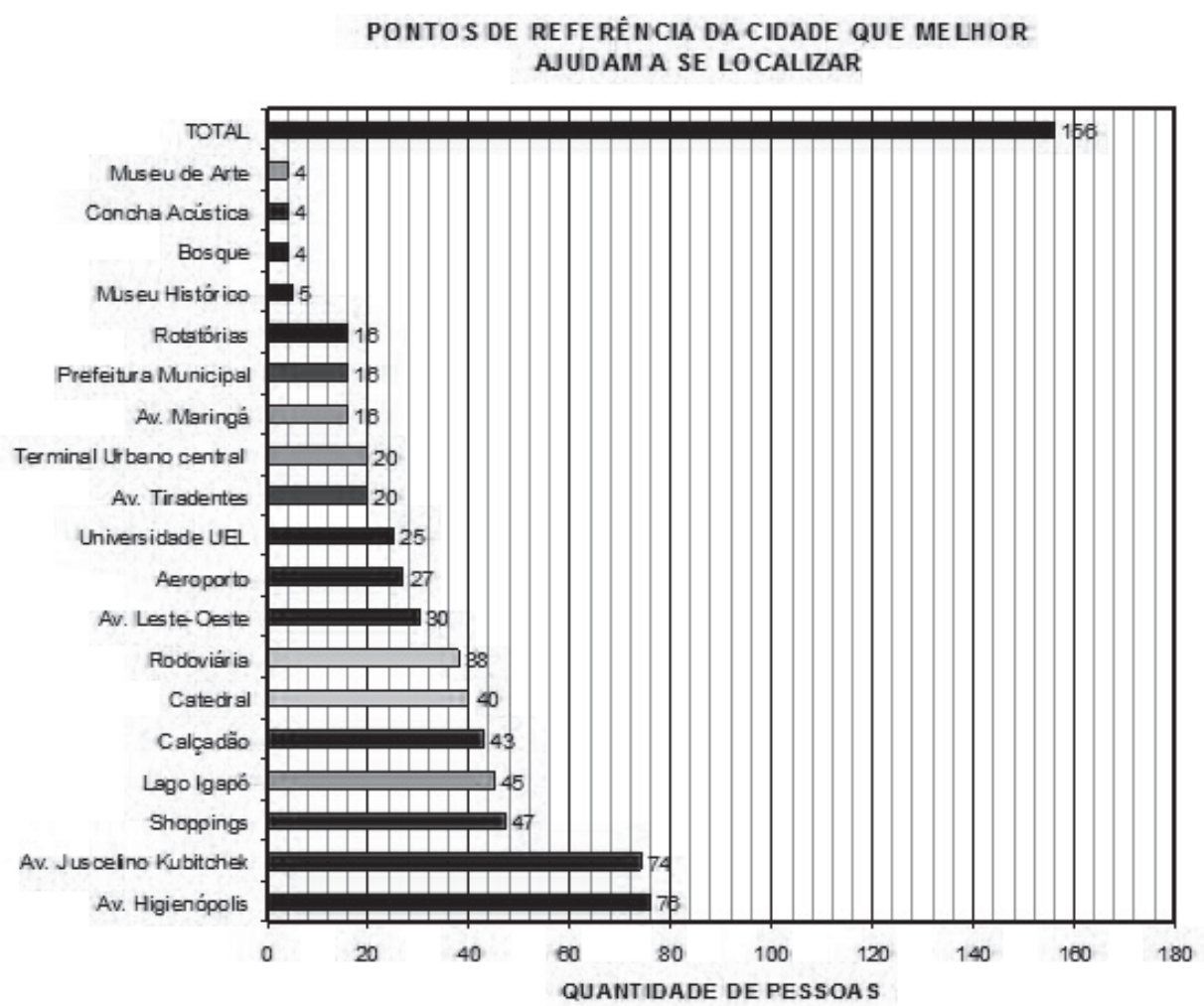

Gráfico 3 - Pontos Referenciais da cidade de Londrina

Fonte: Elaborado pela autora

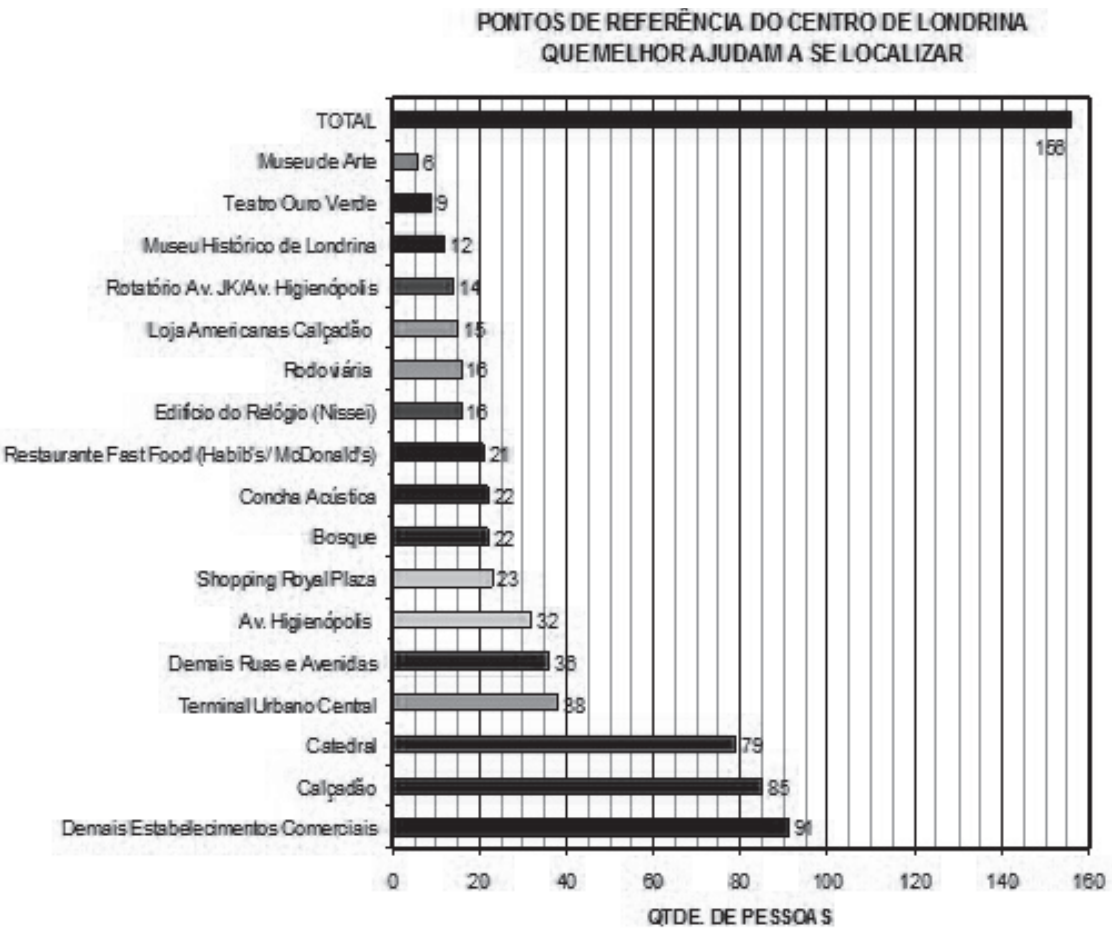

Gráfico 4 - Pontos Referenciais do centro da cidade de Londrina

Fonte: Elaborado pela autora 
Cabe realçar o expressivo destaque que os estabelecimentos comerciais possuem como marco referencial no centro da cidade de Londrina, uma vez que $10 \%$ dos entrevistados mencionaram a rede "Lojas Americanas" como um dos pontos de relevância imagética; $13 \%$ apontaram as redes de fast food (Habib's e/ou McDonald's); e 58\% citaram outras lojas como referência. Os demais pontos maiormente referidos foram: o Calçadão (54\%), a Catedral (51\%) e o Terminal Urbano Central (24\%).

Apósteremrespondido asquestõese, aparentemente, terem parado para verdadeiramente refletir acerca da sua percepção da cidade, os entrevistados eram interrogados a respeito da existência, ou não, em Londrina, de um alguma referência física suficientemente marcante a ponto de se poder relacionar a imagem desta referência rapidamente à cidade. Ou seja, era a busca pela "cara" de Londrina. A esses resultados foram adicionados os resultados do questionário Tipo 02.

$\mathrm{Na}$ seqüência, foi perguntado se existia alguma referência de tal magnitude para os visitantes que na cidade passavam. Os resultados podem ser conferidos nos gráficos 05 e 06.

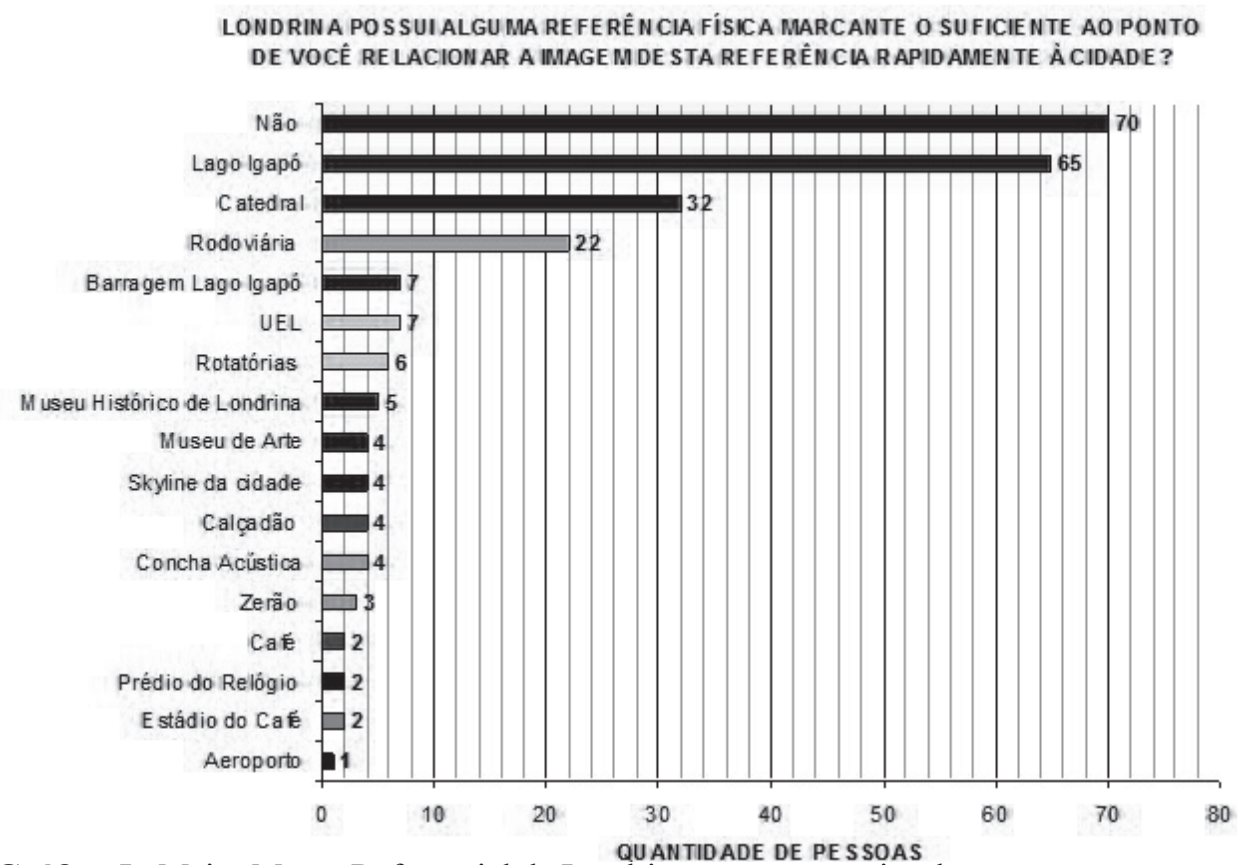

Gráfico 5. Maior Marco Referencial de Londrina para o entrevistado Fonte: Elaborado pela autora

Apesar de o Lago Igapó ter sido mencionado por $42 \%$ dos entrevistados, a Catedral por $20,5 \%$ e a Rodoviária por $14 \%$ deles, é interessante observar que, em uma cidade onde a arquitetura foi privilegiada com obras históricas e de grandes arquitetos (Villanova Artigas, Oscar Niemeyer, etc.), quarenta e cinco por cento dos entrevistados afirmaram não haver um marco referencial de tal magnitude.

De maneira complementar, nota-se que a maioria dos interrogados que responderam sim a essa questão, citaram mais de uma opção como resposta, comprovando a falta de uma identidade ou unicidade do povo de Londrina ao definir um marco referencial principal.

Corrobora esse ponto de vista a análise das repostas feita para a mesma pergunta, uma vez que elas variaram bastante: o Lago Igapó recebeu $44 \%$ dos votos dos entrevistados, seguido pelo "não" com 31\%, a Catedral com $17 \%$ e a Rodoviária com $15 \%$, sendo que, e muitos, ao dizerem sim, citaram vários marcos. 


\section{E PARA VISITANTES DE FORA, HÁ AL GUMA REFERÊNCIA FÍSICA QUE SEMPRE OS FAZEMIDENTIFICAR A CIDADE DE LONDRINA?}

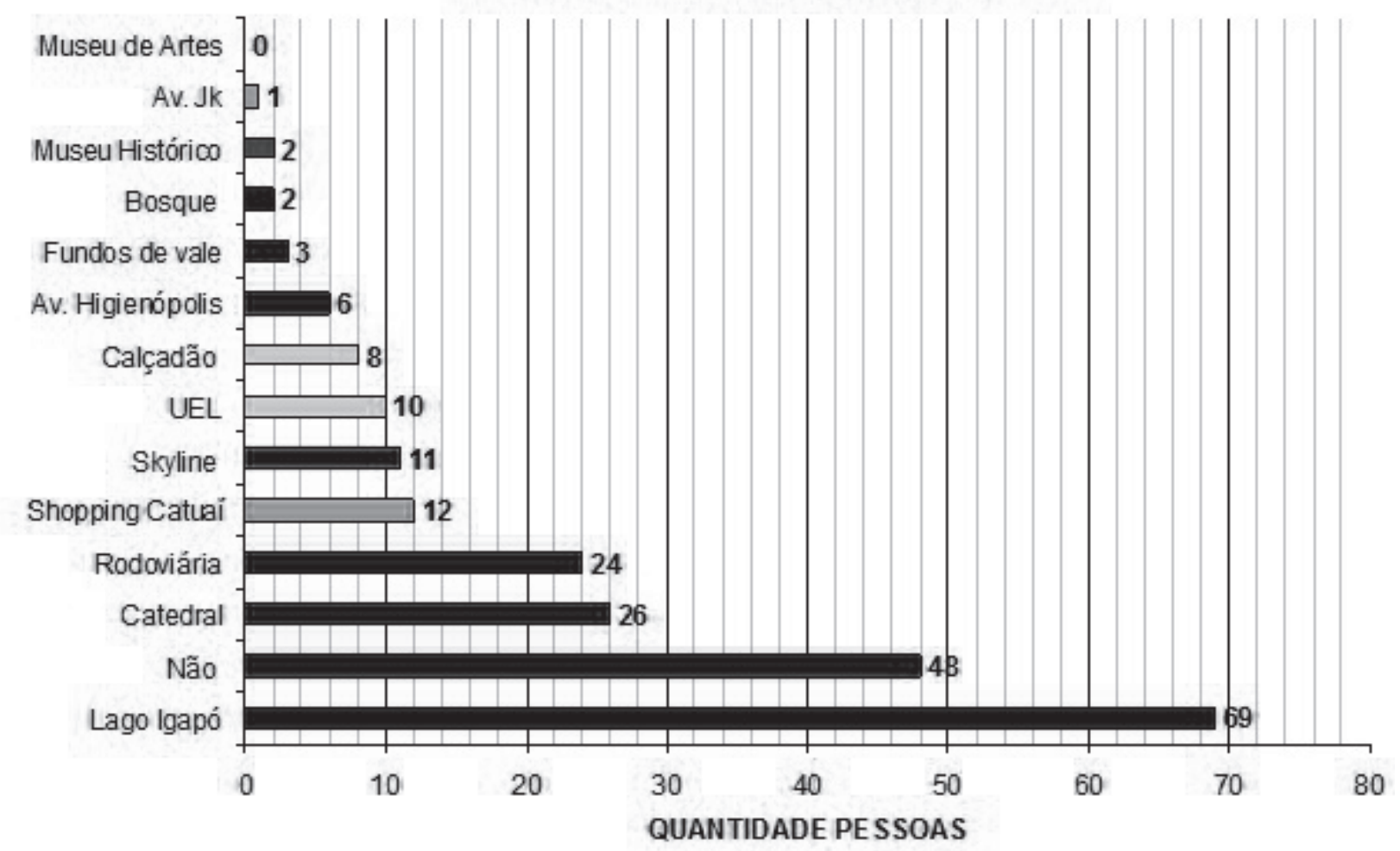

Gráfico 6. Maior Marco Referencial de Londrina para os visitantes Fonte: Elaborado pela autora

Finalmente, foi solicitado ao entrevistado que descrevesse (ou desenhasse) o caminho que faz todos os dias entre o local de sua residência e seu trabalho, ressaltando as referências significativas quanto aos pontos imagéticos que o ajudam a identificar o meio.

Mais uma vez ficou clara a falta de identificação dos interrogados com os marcos históricos importantes para a cidade, uma vez que 93\% deles identificaram nomes de ruas, $67 \%$ indicaram estabelecimentos comerciais e 40\% lembraram de estabelecimentos de ensino. Em contrapartida, apenas 3\% citaram o Museu Histórico de Londrina, $2,5 \%$ ressaltaram a Catedral, $1,5 \%$ identificou a Concha Acústica e ninguém lembrou do Museu de Arte da cidade. Todos esses dados podem ser conferidos no gráfico 07 que segue abaixo. 


\section{PONTOS REFERENCIAIS DESCRIT OS/DE SENHADOS NO CAMINHO DO DIA-A-DIA DOS ENT REVISTADOS}

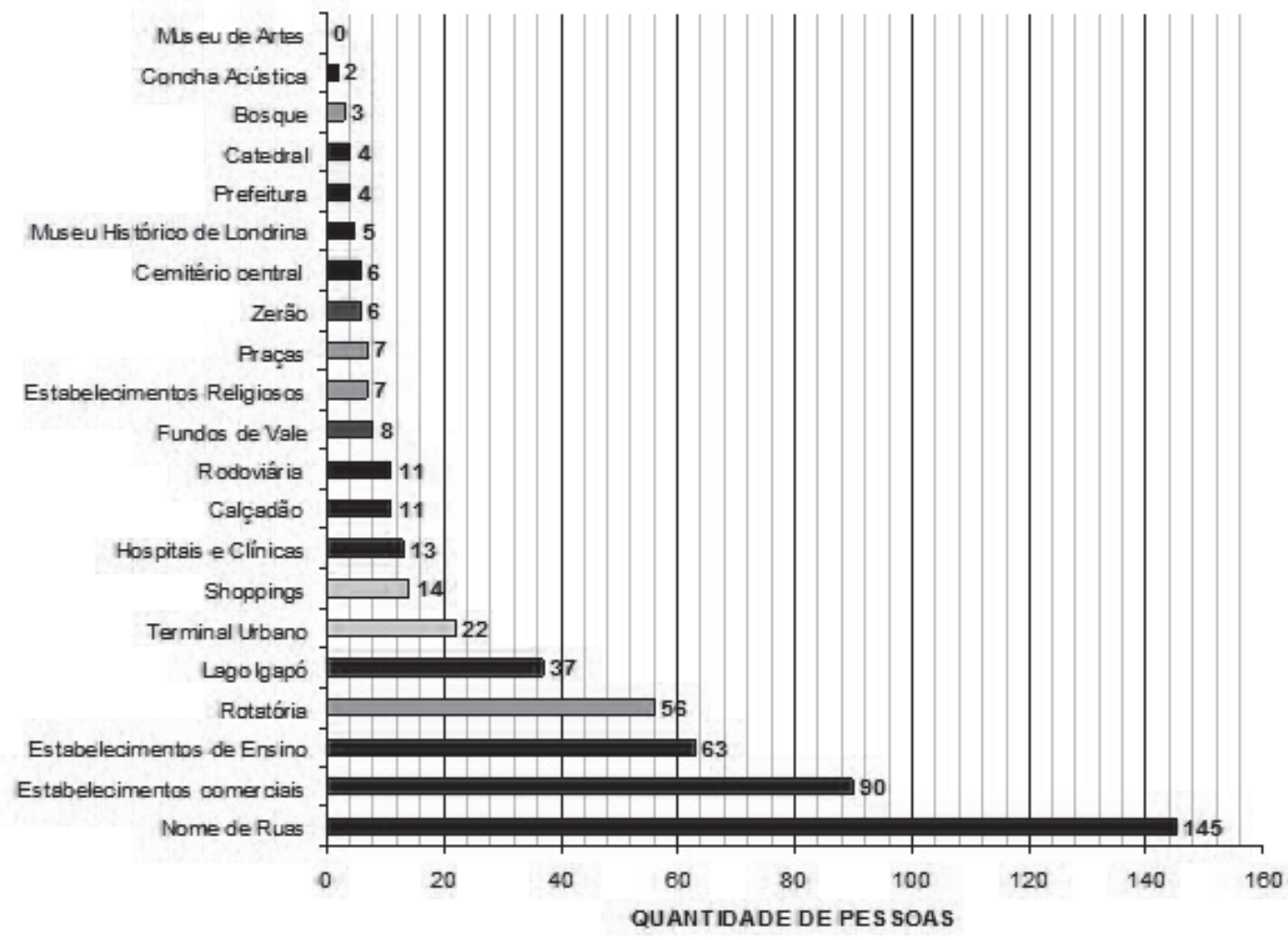

Gráfico 7. Marcos Referenciais descritos/desenhados nos caminhos de seus dia-a-dias Fonte: Elaborado pela autora

Ademais, nos comentários dos entrevistados acerca da cidade, as respostas foram bem homogêneas: a grande maioria vê Londrina como uma cidade bastante acolhedora, mas que está se tornando muito violenta. Além disso, boa parte dos antigos moradores afirmou que a cidade está mal cuidada. Outros dados podem ser verificados com os depoimentos selecionados que seguem:

Nasci aqui, e aqui me sinto em casa! Apesar de achar a cidade meio suja e mal cuidada atualmente, acho Londrina uma cidade calorosa. $\mathrm{O}$ centro é meio complicado, principalmente o trânsito. ${ }^{4}$
Londrina apresenta atrativos culturais e educacionais muito fortes e que estimulam a vinda de novos moradores. Além disso, a configuração espacial da cidade permite que se tenha uma apreensão facilitada dos espaços, principalmente da área central. A verticalização é uma imagem bastante peculiar e característica e parece faltar ligações entre as diversas áreas urbanas, já que muitas pessoas desconhecem bairros por restringirem suas atividades ao centro $^{5}$

Perdeu seu charme nas garras do "progresso". 6

${ }^{4}$ M. E. Funcionária pública. Residente em Londrina há 41 anos. Londrina, 2008. Resposta Questionário.

5 S. T. J. Estudante. Residente em Londrina há 4 anos. Londrina, 2008. Resposta Questionário.

${ }^{6}$ J. C. O. Webdesigner. Residente em Londrina há 51 anos. Londrina, 2008. Entrevista concedida a autora. 
Para mim, é o principal lugar do mundo, o centro do meu mapa mundi individual. Noto agora um certo envelhecimento (cor dos edifícios por exemplo) que a deixam mais charmosa. Pro outro lado sinto bastante quando pontos que foram referências para mim no passado e não estão mais lá (casa pararoquial, muitas casas residenciais do centro etc.). ${ }^{7}$

Cidade dotada de boa infra-estrutura, necessitando de melhorar equipamentos de saúde, segurança e moradia popular. (Possuidora de lindos vales, População jovem numerosa, Povo acolhedor). ${ }^{8}$

Acho-a uma cidade maior que do a capacidade das pessoas em dirigí-la. Em se tratando de uma cidade de 500 mil hab., entendo que deveria se ter uma visão maior em relação aos seus problemas e quando essa visão existe, os problemas são tratados de forma primitiva, provinciana e, na maiorias das vezes, os mesmo não são solucionados. Eu poderia discorrer muito sobre isso, mas em síntese é isso. ${ }^{9}$

Adoro Londrina, o parque e o lago são a "cereja do bolo" da cidade. A única coisa que esta acabando com a cidade é a violência. ${ }^{10}$

Gosto muito de morar em Londrina. Acho que se parasse de crescer seria melhor, pois já está apresentando vários sintomas de cidade grande, como violência e trânsito congestionado em alguns horários. ${ }^{11}$

Feia, com grande crescimento em periferias totalmente desordenadas, esburacada! ${ }^{12}$
Bonita, mas falta um bom planejamento para adequar e incentivar o crescimento da cidade. ${ }^{13}$

Acho muito bonita e acolhedora, mas muito mal cuidada pelo governo e pelos moradores. ${ }^{14}$

Agradável, ainda carrega algumas características de cidade pequena, embora seja uma região metropolitana. ${ }^{15}$

Um pouco violenta porem bem acolhedora. ${ }^{16}$

Foi justamente a partir da conversa com um desses entrevistados que a análise iconográfica pretendida por este artigo obteve seu ímpeto inicial. Residente há mais de 58 anos na cidade de Londrina e com 80 anos de idade, o senhor José evidenciou outro fato crucial para o trabalho: o processo de descaracterização de pontos imagéticos para a cidade de Londrina foi ocorrendo lentamente ao longo do crescimento e da urbanização da mesma. O contador aposentado demonstra que em diferentes períodos tais pontos já foram mais expressivos.

Antigamente era mais fácil responder perguntas como esta porque a cidade era menor [...] tinha bem poucos prédios e as coisas grandes se destacavam na paisagem. [...] acho que, com certeza, a estação ferroviária, o Fuganti, o Colégio Mãe de Deus [...] eu já acho que hoje tudo é lindo [...] eu fico abismado de ver como cresceu a cidade [...] acho que o Royal... o Carrefour... o Igapó... não me lembro mais de nenhum. ${ }^{17}$

De acordo com as três frases finais de José citadas acima - e em conformidade com as demais respostas obtidas nos questionários, concluiu-se que este processo de descaracterização de Londrina

\footnotetext{
7 L.M.C. Professora Universitária. Residiu em Londrina entre 1956-1980. Londrina, 2007. Entrevista concedida a autora.

8 N.R.Urbanista. Residente em Londrina há 40 anos. Londrina, 2008. Resposta Questionário.

9 E.M. Servidor Público Estadual da área de fiscalização de obras. Residente em Londrina há 51 anos. Londrina, 2008. Resposta Questionário.

${ }^{10}$ C. Y. Publicitário. Freqüente Visitante à Londrina. Londrina, 2008. Resposta Questionário.

${ }^{11}$ F. A. Programador Aposentado. Residente em Londrina há 41 anos. Londrina, 2007. Entrevista concedida a autora.

${ }^{12}$ E. P. Administrador. Residente em Londrina há 27 anos. Londrina, 2007. Resposta Questionário.

13 S. M. Arquiteto. Residente em Londrina há 18 anos. Londrina, 2008. Resposta Questionário.

${ }^{14}$ M. G. Arquiteta e Urbanista. Residente em Londrina há 13 anos. Londrina, 2008. Resposta Questionário.

${ }^{15}$ L. P. Arquiteta e Urbanista. Residente em Londrina há 2 anos. Londrina, 2008. Resposta Questionário.

${ }^{16}$ G. M. Técnico em Sistemas de Informação. Residente em Londrina há 17 anos. Londrina, 2008. Resposta Questionário.

17 J.O. Contador aposentado. Londrina, 2007. Entrevista concedida à Olívia Orquiza de Carvalho.
} 
decorreu, também, da mudança no estilo de vida dos habitantes da cidade, uma vez que, cada vez mais envolvidos na correria do dia-a-dia, acabam citando como pontos referenciais mais marcantes os bancos, os shoppings, os mercados etc.

Levando em conta tudo que foi dito até o momento, faremos, a seguir, uma análise pontual das possíveis patologias urbanas que vem causando o desaparecimento da significação das imagens dos marcos históricos nas visões seriais dos transeuntes de Londrina.

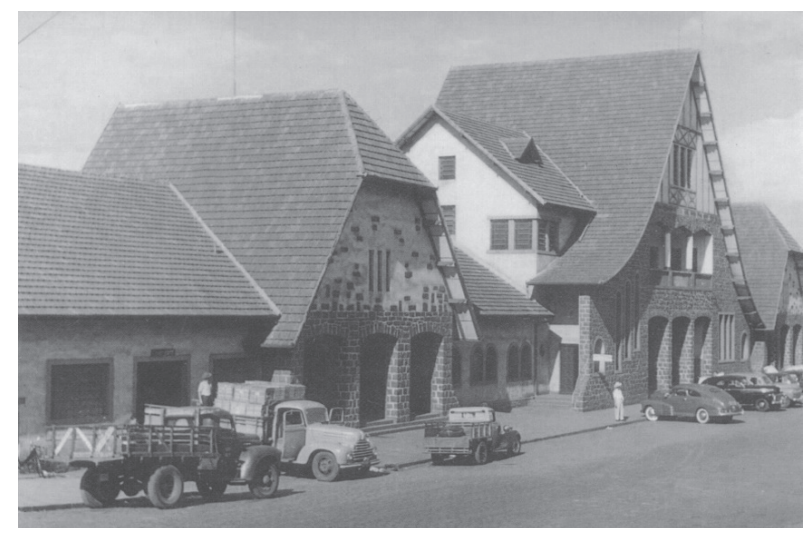

Figura 1. Estação Ferroviária

Fonte: Acervo Museu Histórico de Londrina

Já nas fotos mais recentes, nota-se que não há uma fácil legibilidade do edifício devido às grotescas grades e placas que o cercam e ele também perdeu o domínio do horizonte (constatado nas fotos 03 e 04 pelos prédios

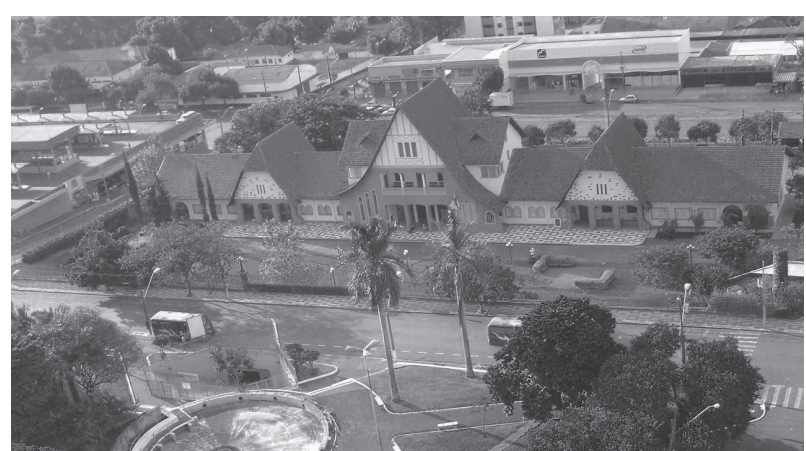

Figura 3. Museu Histórico de Londrina

Fonte: Acervo pessoal da Autora.

\section{Ponto a Ponto}

O primeiro ponto a ser analisado é a antiga Estação Ferroviária ou atual Museu Histórico de Londrina. Conforme podemos perceber na comparação entre as duas fotos antigas e as duas fotos atuais seguintes, este edifício, apesar não ter sofrido muitas mudanças físicas ao longo dos anos, foi perdendo o destaque na paisagem da cidade.

Nas fotos mais antigas, é visível como ele destoa bastante do horizonte ao fundo e da praça a sua frente. Percebemos, ainda, que há uma conexão muito maior do edifício com seu entorno e que seu acesso era feito de maneira mais fácil devido à sua função de Estação Ferroviária e à falta de obstáculos.

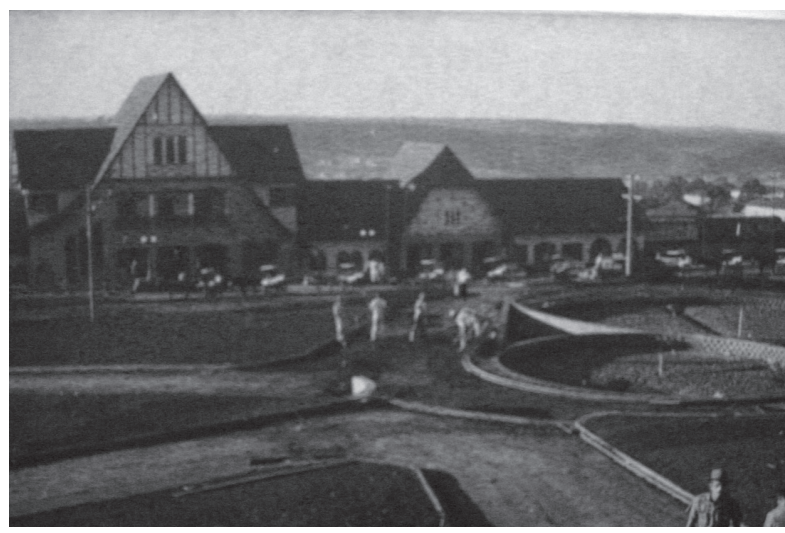

Figura 2. Estação Ferroviária

Fonte: Acervo Museu Histórico de Londrina

ao redor). Além disso, com a mudança de sua utilização, o edifício acrescentou outro tipo de barreira, conhecida pelos arquitetos e urbanistas como psicológica, que acabou distanciando o público.

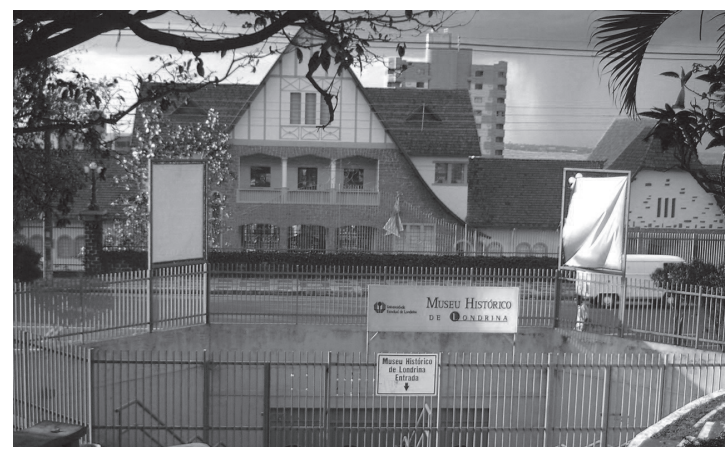

Figura 4. Museu Histórico de Londrina

Fonte: Acervo pessoal da Autora. 
Outro ponto importante a ser analisado é a Catedral de Londrina. Ao longo de sua história a

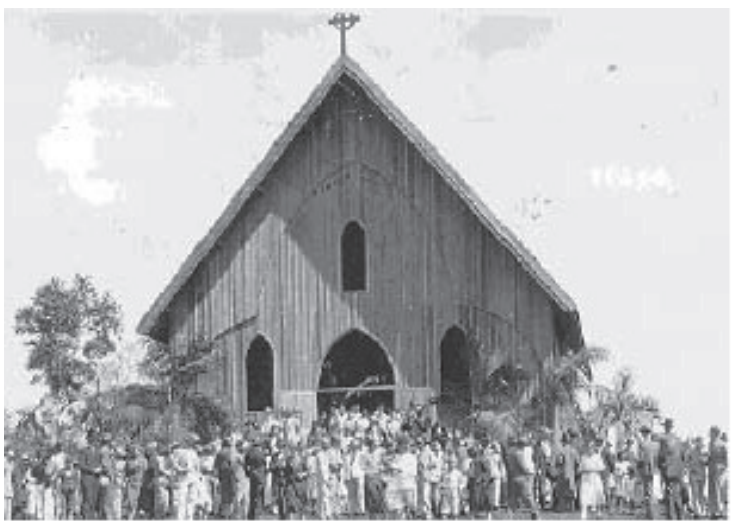

Figura 5. Primeira Catedral (década 1930)

Fonte: CODEL (2007)

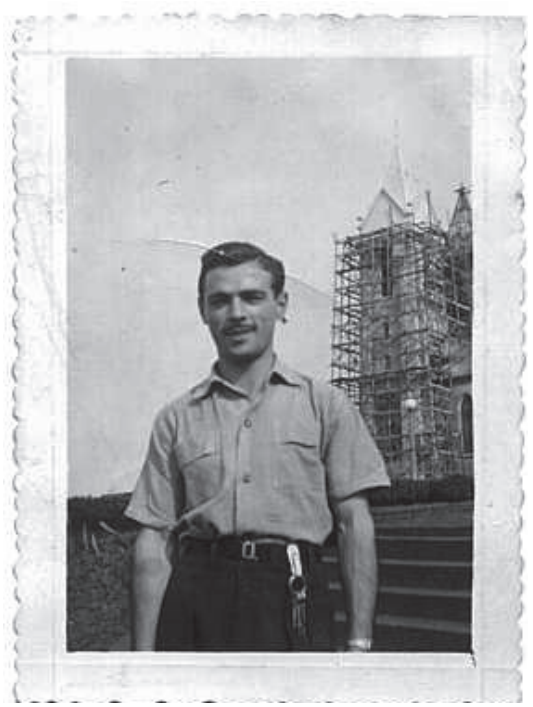

Figura 7. Segunda Catedral sendo Construída (Década 1940) Fonte: Acervo Família Orquiza.

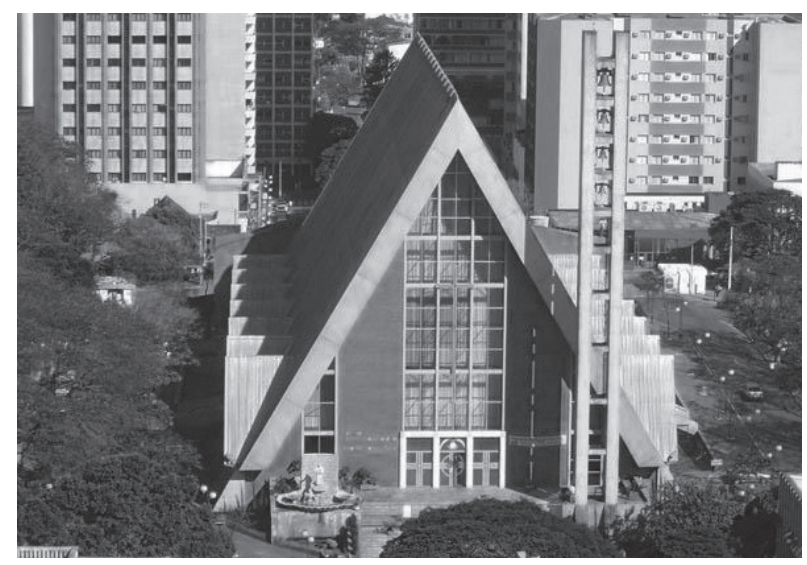

Figura 9. Atual Catedral

Fonte: Londrina (2007a) cidade já teve três diferentes catedrais.

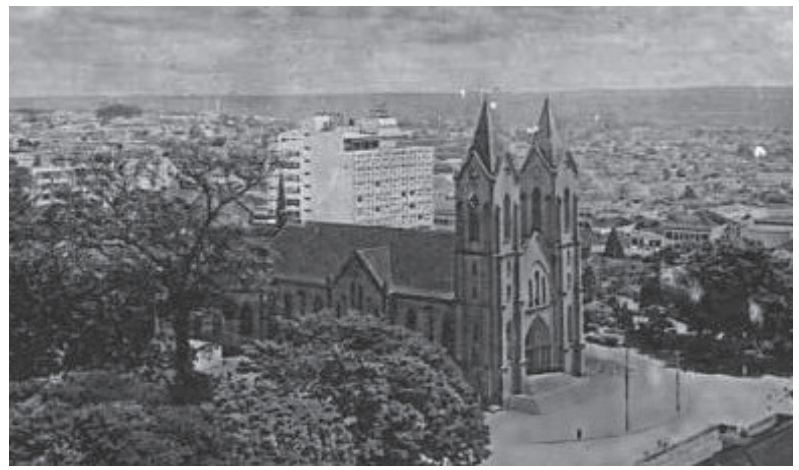

Figura 6. Segunda Catedral (postal)

Fonte: Acervo Família Orquiza

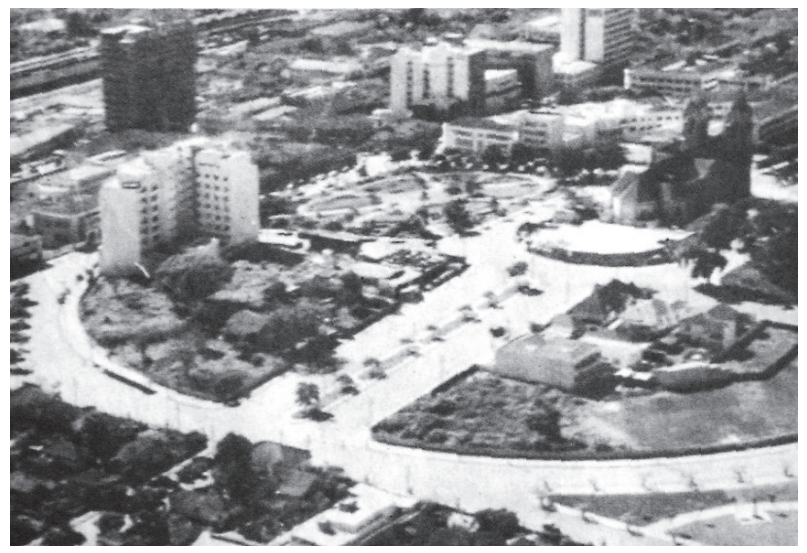

Figura 8. Segunda Catedral (Década 1950)

Fonte: Acervo Museu Histórico de Londrina

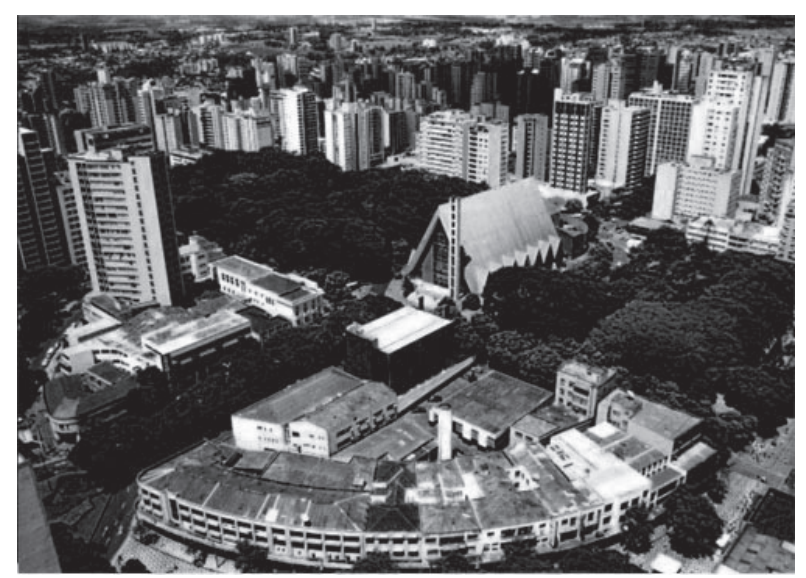

Figura 10. Atual Catedral e entorno

Fonte: Fonte desconhecida 
As fotos dispostas acima evidenciam que, apesar da clara tentativa de manter a catedral sempre em posição privilegiada na cidade, ela também perdeu sua soberania na paisagem urbana. A primeira, construída em 1934 no ponto mais alto da cidade, foi projetada para ser o epicentro do projeto urbanístico original feito pelo engenheiro Alexandre Razgulaeff. Assim, pode se dizer que representava um grande marco no vilarejo que já havia se formado.

Na década de 1940, esta primeira catedral, de madeira, foi substituída por outra de estilo neogótico (fotos 06,07 ). A paisagem da cidade já havia sofrido grandes mudanças decorrentes do aumento de quase cinco vezes do número de habitantes, contudo a catedral continuava a destacar-se do entorno de edificações de pequeno e médio porte (figura 08). Além disso, ainda se era possível distinguir com clareza as praças e o anel ao seu redor.

No início da década de 1970, mais uma vez a catedral foi substituída. $O$ entorno já se apresentava bem modificado. Altos prédios tomavam conta do horizonte e as praças circundantes da catedral não se mostravam mais tão destoantes. De lá para cá, essa situação só se tem agravado e hoje a localização na área central se apresenta bastante dificultada pela massa de edificios, árvores, sinais e placas que a sufocam. A catedral perdeu muito o seu potencial de marco na cidade (fotos 09 e 10).

O terceiro ponto a ser analisado é o atual Museu de Arte de Londrina, junto da Praça Rocha Pombo localizada logo à sua frente.

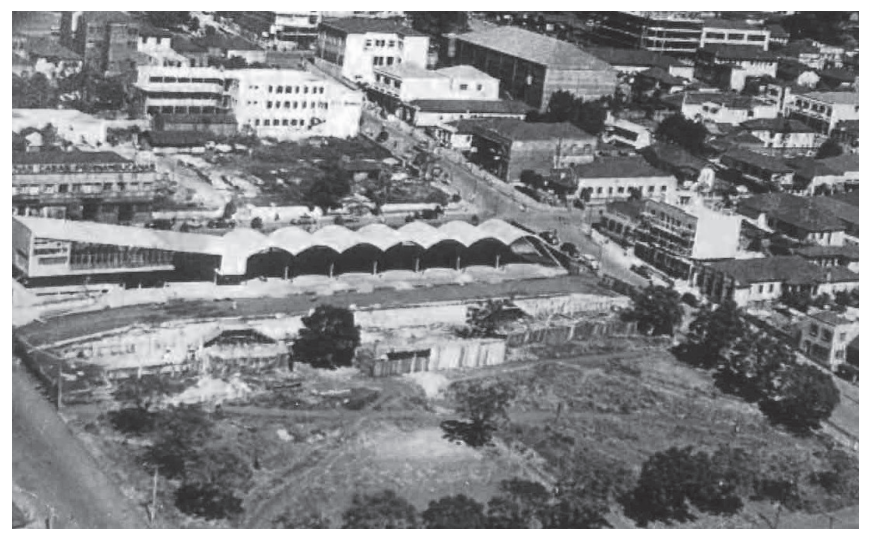

Figura 11. Rodoviária e Praça Rocha Pombo Fonte: Acervo Museu Histórico de Londrina.

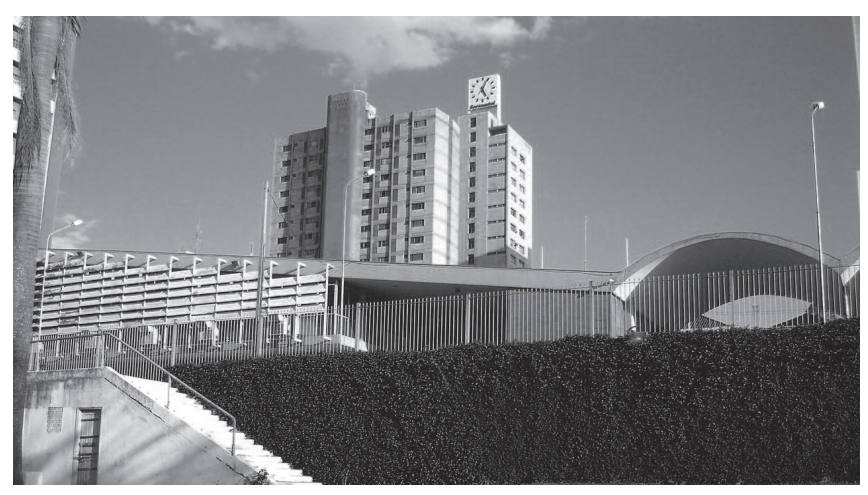

Figura 13. Vista dos fundos do Museu de Arte Fonte: Acervo pessoal da Autora.

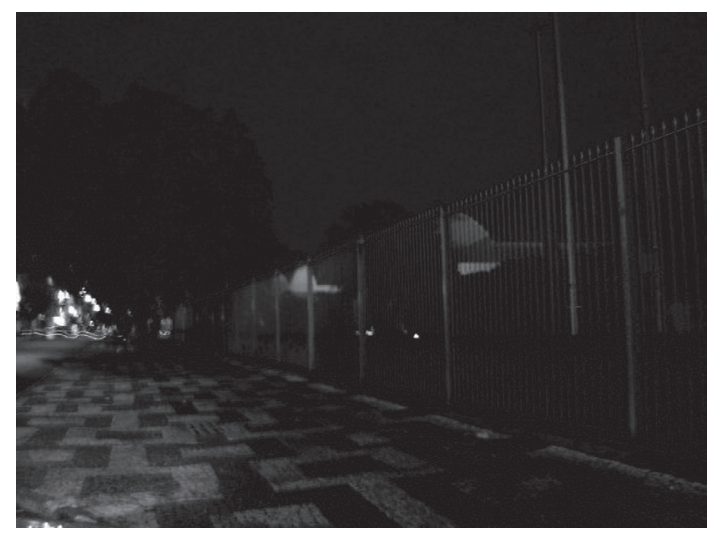

Figura 12. Fachada atual do Museu

Fonte: Acervo pessoal da Autora.

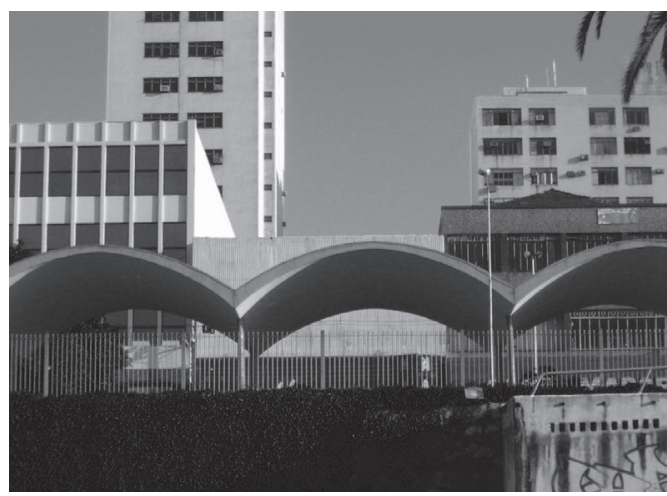

Figura 14. Vista do Museu da Praça

Fonte: Acervo pessoal da Autora. 
Comparando a foto antiga com as atuais, é possível perceber que os dois elementos analisados sofreram as mesmas patologias dos primeiros exemplos, ou seja, ao longo dos anos foram perdendo a "intensidade" da sua imaginabilidade devido ao entorno que os engoliram. Pode-se ressaltar, também, que, como no Museu Histórico, as grades e demais barreiras psicológicas serviram para espantar mais do que os vândalos, pois afastaram os londrinenses em geral.

Seguindo este raciocínio, outros pontos da cidade foram analisados e classificados como possuidores destes mesmos efeitos patológicos citados acima. Esses pontos podem ser identificados nas imagens seguintes:

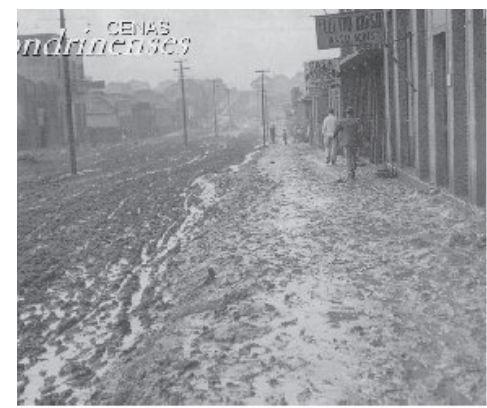

Figura 15. Av. Paraná (1930) Fonte: Londrina (2007b

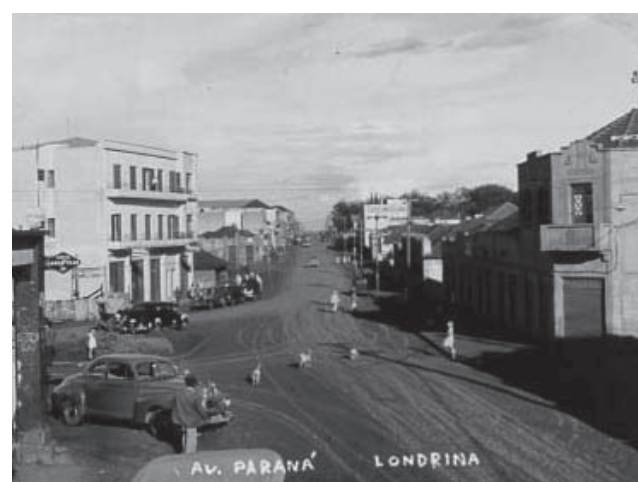

Figura 16. Av. Paraná (década 1940)

Fonte: Carro Antigo (2007)

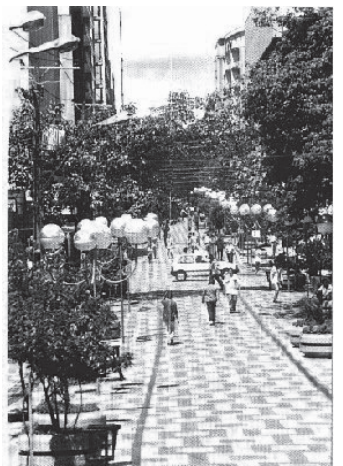

Figura 17.Atual Av. Paraná Fonte: Londrina (2007b)

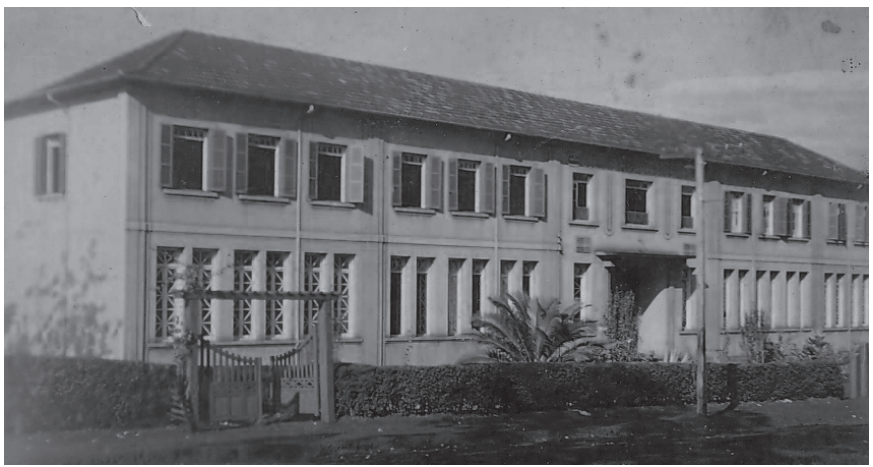

Figura 18. Colégio Mãe de Deus

Fonte: Acervo da família Orquiza

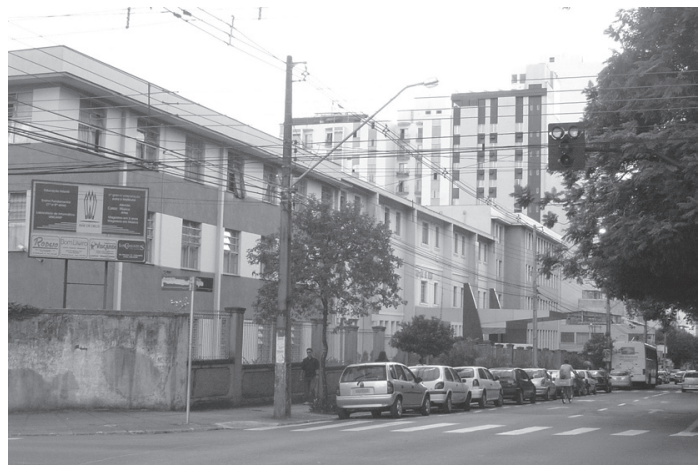

Figura 19. Colégio Mãe de Deus Fonte: Acervo pessoal da autora. 


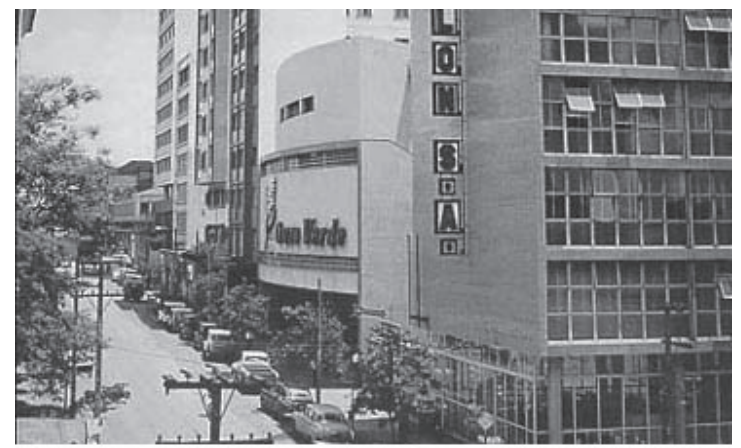

Figura 20. Cine Ouro Verde (Década 1960) Fonte: Carro Antigo (2007)

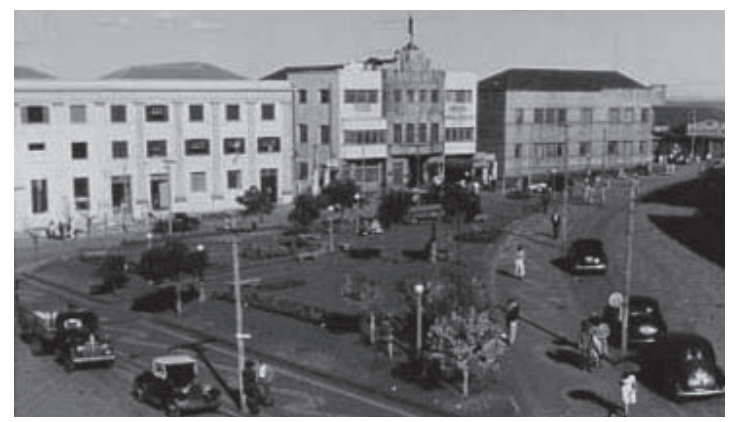

Figura 22. Praça Willie Davis (1940)

Fonte: Museu Histórico de Londrina.

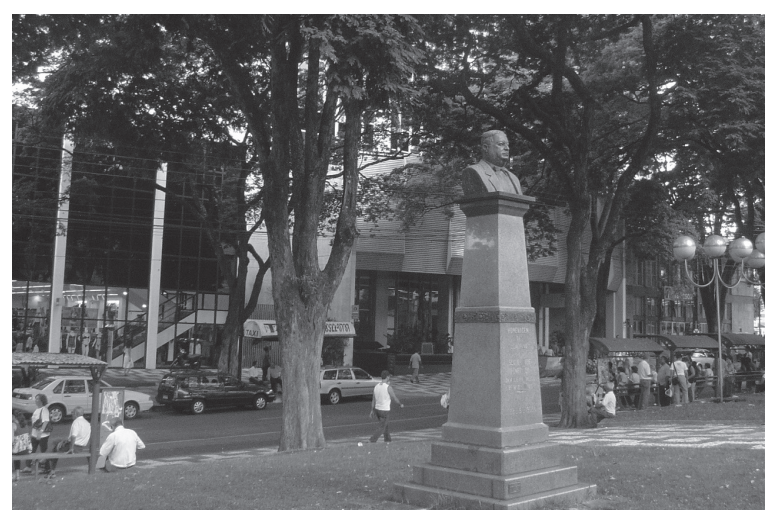

Figura 23. Praça Willie Davis atualmente Fonte: Acervo pessoal da autora

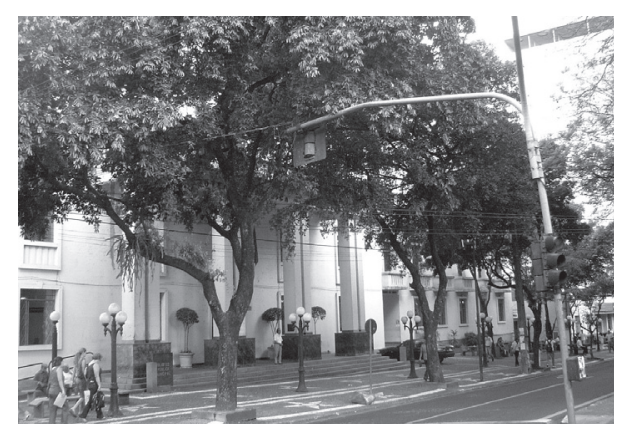

Figura 25. Atual Biblioteca Municipal Fonte: Acervo pessoal da autora

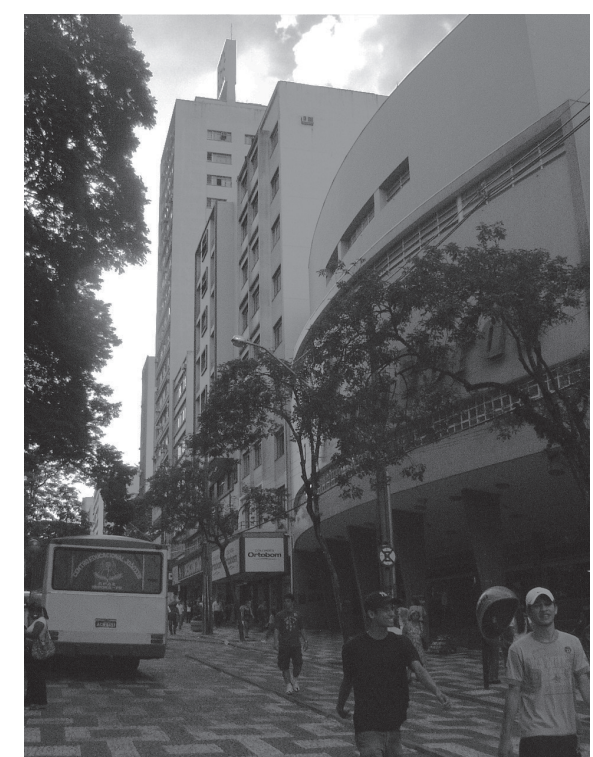

Figura 21. Cine Ouro Verde atualmente Fonte: Acervo pessoal da autora

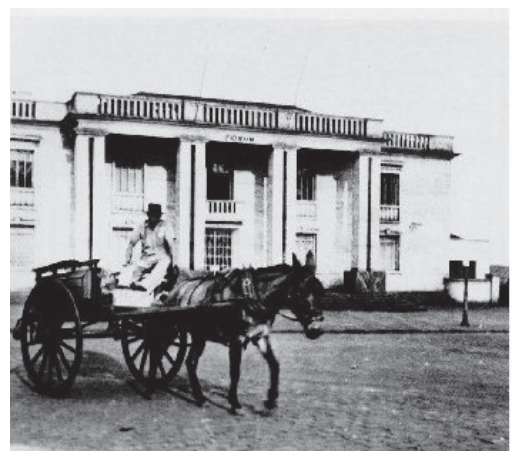

Figura 24. Antigo Fórum da cidade Fonte: Londrina (2007b)

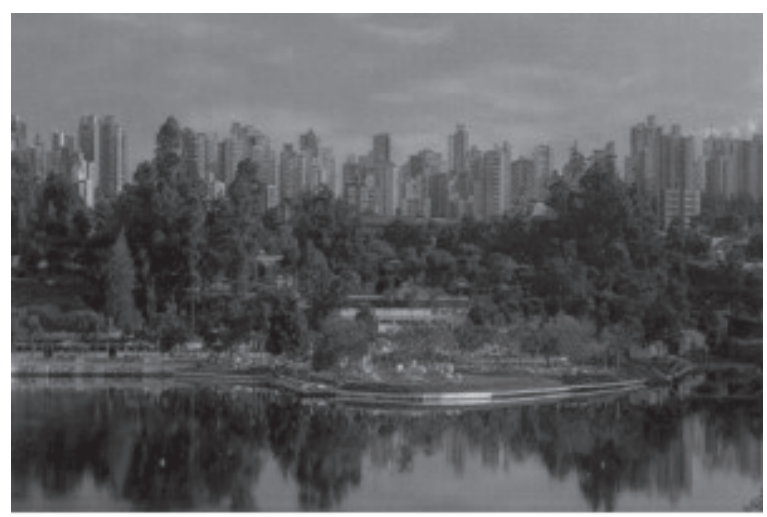

Figura 26. Lago Igapó

Fonte: Londrina (2007b) 


\section{Considerações Finais}

De modo geral, as pessoas entrevistadas afirmaram ver Londrina como um local belo, acolhedor e de fácil locomoção. No entanto, na hora de dar nome aos pontos de referência ou de desenhar evidenciavam que não apenas se confundiam ao relacionar pontos da cidade entre si (em termos de orientação e localização), como também não apresentavam homogeneidade nas respostas quanto aos marcos, comprovando a falta de ícones comuns a todos.

A maioria se lembrava de ruas, estabelecimentos comerciais, outdoors, ou até mesmo de depósitos de lixos nas redondezas das suas residências, porém ao responder a questão acerca das referências existentes no centro da cidade foram diversas as respostas. Os poucos pontos que sobressaíram foram: o Calçadão, a Catedral e o Terminal Urbano Central. Pouquíssimos se lembraram do Museu Histórico de Londrina, do Museu de Arte, do Bosque e da Concha Acústica.

Assim, pode-se dizer que, ao longo de sua história, Londrina teve pontos imagéticos importantes que chegaram a servir de referência para a cidade. Entretanto, por ter evoluído de um modo indeterminado e espontâneo, ela foi perdendo estes pontos nos entremeios da massa urbana polifônica crescente, a qual não só muitas vezes ofuscou o brilho destas imagens da cidade, como, ainda, não fez um bom trabalho para repô-las.

Hoje, Londrina encontra-se muito mais monótona que antigamente e sem um ícone único de identidade que evoque sua imagem em outros cantos do mundo. Ademais, os poucos pontos possuidores de uma imagem pública significativa estão desaparecendo cada vez mais.

Por fim, desabafa-se aqui que, por sermos seres urbanos, somos autores da nossa cidade, ou seja, construtores permanentes de sua rede de significação. Portanto, um significativo e perpétuo cuidado necessita ser tomado, o quanto antes, por parte de todos, pois este processo de anulação de marcos imagéticos, importantes para o bom relacionamento dos habitantes com a cidade, continuará se agravando e culminará na sua extinção, resultando em uma cidade acinzentada, mal vista, amorfa e composta por muitos "não lugares", como muitas outras cidades, brasileiras e internacionais, já existentes que apresentam níveis mais avançados desta patologia.

\section{Referências}

CANEVACCI, Mássimo. A cidade polifônica: ensaio sobre a antropologia da comunicação urbana. São Paulo: Studio Nobel, 1993.

CARRO Antigo. Disponível em: < www.carroantigo.com. br>. Acesso em: abril 2007.

CULLEN, Gordon. Paisagem urbana. São Paulo: Martins Fontes, 1984.

FERRARA, Lucrecia. Os significados urbanos. São Paulo: Ed. da Universidade de São Paulo: Fapesp, 2000.

INSTITUTO DE DESENVOLVIMENTO DE LONDRINA - CODEL. Disponível em: <www.codel. londrina.pr.gov.br>. Acesso em: abr. 2007.

LONDRINA express. Disponível em: <www. londrinaexpress.com.br>. Acesso em: abr. 2007a.

LONDRINA. Prefeitura Municipal. Disponível em: $<$ www.londrina.pr.gov.br>. Acesso em: abr. 2007b.

LYNCH, Kevin. A imagem da cidade. São Paulo: Martins Fontes, 1997.

SANTAELlA, Lucia. O que é semiótica. São Paulo: Brasiliense, 2005b.

Semiótica aplicada. São Paulo: Pioneira Thompson Learing, 2005a.

SILVA, Jussara Maria. Os marcos referenciais na estruturação sócio-espacial da cidade de Concórdia -SC. 2001. Dissertação (Mestrado em Geografia) Departamento de Geografia, Universidade Federal do Paraná, Curitiba.

TAVARES, Maria Tereza Goudard. A cidade e a alfabetização das crianças das classes populares: algumas considerações. 1985. Disponível em: <http:// www.anped.org.br/reunioes/25/mariaterezatavarest06. rtf $>$. Acesso em: jul. 2007. 
